\title{
Evaluation of Moto-Stand A New Vehicle for Upright Ambulation in Paraplegics
}

\author{
M. A. Medhat, M.D.; ${ }^{1}$ V. Nanda Kumar, M.D.; ${ }^{2}$ and J. B. Redford, M.D. ${ }^{3}$ \\ ${ }^{1}$ Ass't. Professor in Rehabilitation Medicine, ${ }^{2}$ Chief, Rehabilitation Medicine \\ Service and ${ }^{3}$ Professor and Chairman, Rehabilitation Medicine Department, The \\ University of Kansas College of Health Sciences and Hospital, Kansas City, KS \\ 66103, U.S.A.
}

\section{Summary}

The Moto-Stand is a motorised vehicle to propel paraplegics in the upright position. It safely allows handicapped persons a wide range of working capabilities and extends mobility far beyond the limits of a wheelchair. Twenty adults with spinal lesions were evaluated for using the Moto-Stand. The levels of lesion ranged from $C_{6}$ to $L_{1}$. The tetraplegics studied had incomplete lesions and they could get on the MotoStand but needed some assistance. All the paraplegics studied were able to use the Moto-Stand independently. The Moto-Stand was found to be superior for kitchen activities, especially when handling hot objects and reaching objects at different levels. As it turns in its own space it offers superior manoeuverability in the limited space of a kitchen, workshop or even a trailer home. Subjects with moderate to severe spasticity appear to have difficulty in using the Moto-Stand. It was found to be safe and comfortable by the majority of subjects studied.

\section{Introduction}

A portable, collapsible, indoor vehicle became available in 1961 called Stand Alone. The user stands on a platform on four small wheels. Two large propulsion wheels similar to the handrims of a wheelchair $(38 \mathrm{cms}$ in diameter $)$ are connected by a chain with the rear wheel on the same side. A paraplegic with a spinal cord lesion at the eighth thoracic level will require moderate assistance to transfer between the rolling Stand Alone and a wheelchair and for higher lesions more mechanical assistance is required. By the use of toe loops and three pads (one each against the knees, the abdomen and the buttocks), the patient stands in this device without braces and without holding on to the device. In this position the upper limbs are free for desired activity and able to reach objects at the level of a standing person. 
A motorised version became available in the mid 1970s, but both of these vehicles are usually too large to use in an office or home.

The Moto-Stand was designed and built by an engineer who is a paraplegic. This device allows the paraplegic a wide range of capabilities and mobility far beyond the limits of a wheelchair, yet turns within its own space, making it easily manoeuverable in the limited space of a home, office or workshop.

\section{Moto-Stand}

The basic construction of the Moto-Stand consists of a platform supported by two larger wheels in front and one smaller wheel in the rear with a ground clearance of $4 \mathrm{cms}\left(1 \frac{1}{2}^{\prime \prime}\right)$. The rear wheel is driven by a motor powered by a 12 volt battery. There is a well padded (' $\mathrm{T}$ ' foam) vertical mount directly placed over the front wheels whose height can be adjusted for the paraplegic's height. On the top of the vertical mount are placed the controls which include a toggle switch (on-off), battery power indicator, and a horizontal steering rod in the middle. On the side of the vertical mount there are two adjustable belts used to strap the paraplegic in position (Figs 2 and 3). The motor has two forward speeds and reverse. Brakes are placed on both front wheels and are controlled manually by turning a knob on the vertical mount. The Moto-Stand has a width of $55 \mathrm{cms}\left(21 \frac{1}{2}^{\prime \prime}\right)$, and weighs $60 \mathrm{kgs}$ (130 pounds). It has a turning radius of $90 \mathrm{cms}\left(36^{\prime \prime}\right)$.

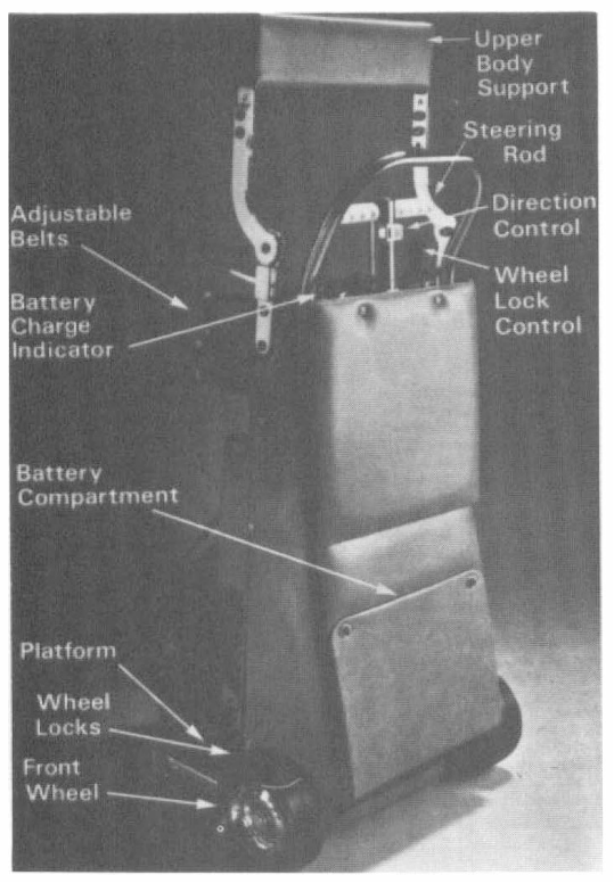

Figure 1. Moto-Stand showing the various parts. 


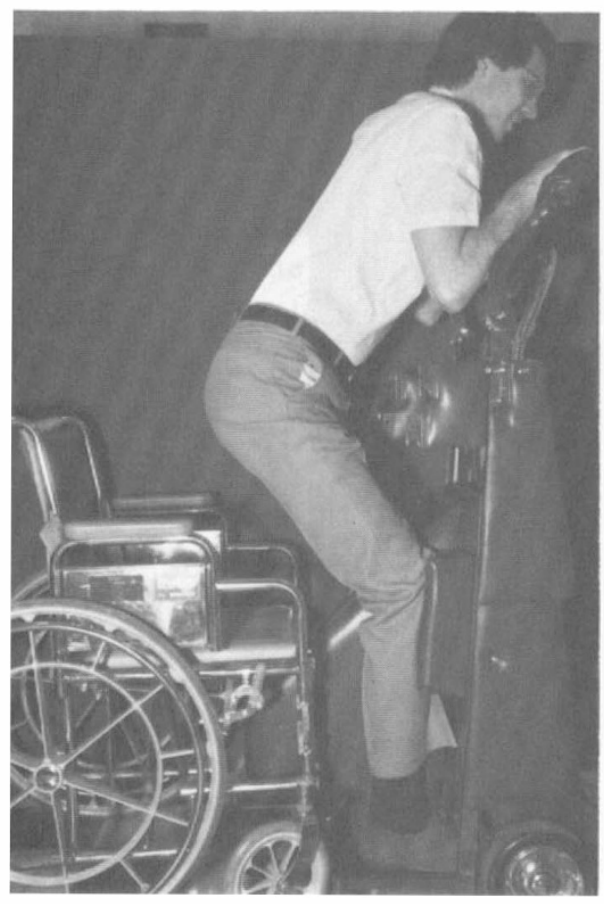

Figure 2. Subject in the process of getting on to the Moto-Stand.

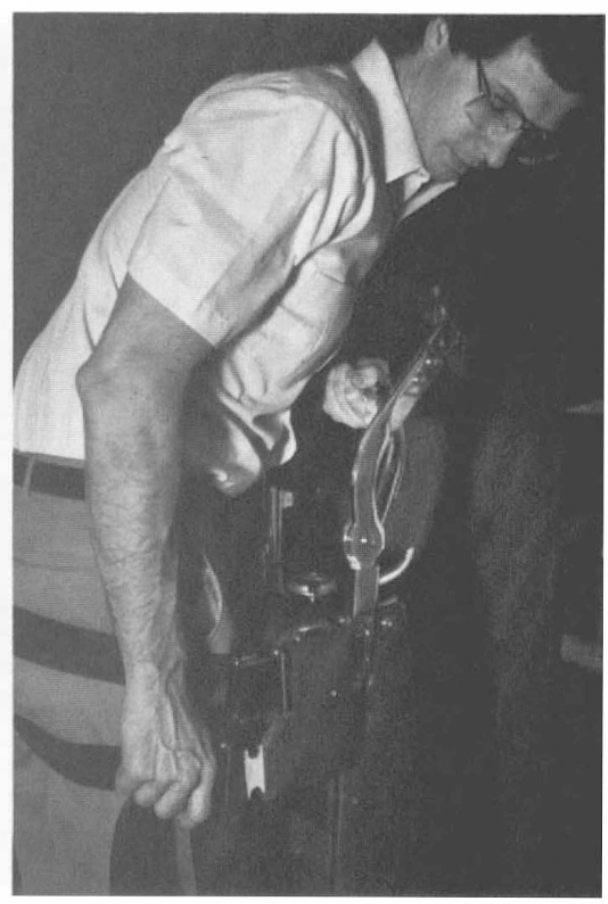

Figure 3. Subject using the two belts to stabilise himself.

\section{Methodology}

We studied 20 subjects with spinal cord disorders with lesions at various levels. The criteria for selection of subjects for trial use of the Moto-Stand were:

1. Patients with a spinal cord lesion below $\mathrm{C}_{6}$ level.

2. Heights not less than $150 \mathrm{cms}\left(5^{\prime}\right)$, and not more than $185 \mathrm{cms}\left(6^{\prime} 2^{\prime \prime}\right)$.

3. Patients weighing less than $115 \mathrm{~kg}$ ( 250 pounds).

4. Patient presently wheelchair-bound.

Before a trial of a Moto-Stand a thorough clinical examination was undertaken for exact motor and sensory level, respiratory function, presence of spasticity, presence of contractures in the lower extremities and upper extremity coordination. The subject was then allowed to get on to the Moto-Stand and to move around. He was asked to go up and down ramps and manoeuvre in a kitchen setting which included working near a hotplate and also working near a dining table to serve food. Other activities included working in a laboratory setting. After various activities, while standing in the Moto-Stand for 60 minutes, the subject returned to the wheelchair. Clinical examination was repeated to see if any pressure areas over the bony prominences had developed, especially the front of the knees. The subjects were also asked to comment on comfort, safety and overall impression. 


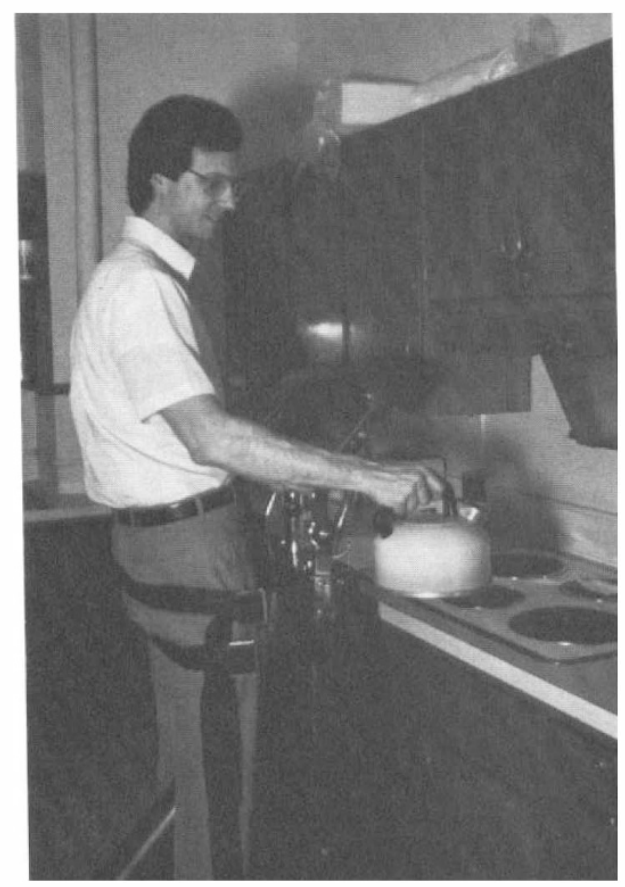

Figure 4. Subject in a kitchen setting.

\section{Results}

Twenty subjects were studies; 19 with spinal cord injury and one with multiple sclerosis and a $T_{10}$ lesion. Nineteen were male and one was female. Ages ranged between 23 and 69 years with a median of 43 years. Twelve were single and eight were married. The heights ranged between $162 \mathrm{cms}$ to $182 \mathrm{cms}\left(65^{\prime \prime}-73^{\prime \prime}\right)$, and median was $175 \mathrm{cms}\left(70^{\prime \prime}\right)$. Weights varied from $53 \mathrm{kgs}$ to $92 \mathrm{kgs}$ (114-200 pounds) with a median of $76 \mathrm{kgs}$ ( 165 pounds). Four were employed, three were students, and 13 were unemployed at the time of evaluation. The years of disability ranged from 2 to 26 years with a median of 8 years. The level of injury ranged between $\mathrm{C}_{6}$ and $\mathrm{L}_{1}$ levels. Three subjects had incomplete cord lesions, two of them were at the level of $\mathrm{C}_{6}$ and one at $\mathrm{C}_{7}$ level. Sixteen had thoracic cord lesions, $\mathrm{T}_{4}$ being the highest, and one had a lumbar lesion.

Clinical assessment for associated musculoskeletal conditions revealed that three subjects had flexion contractures of the hips and knees. Seven had mild spasticity below the lesion and eight had moderate spasticity. Four had Harrington rod fixations and six had spinal fusions. One subject had scoliosis of the spine $\left(15^{\circ}\right)$.

Sixteen subjects were able to transfer from wheelchair to Moto-Stand independently; two needed minimal assistance and two needed moderate assistance. Those who needed assistance had cervical and high thoracic lesions. For transfer from the Moto-Stand to the wheelchair 16 subjects managed this independently, three required minimal assistance and two moderate assistance. For kitchen 
activities 15 subjects ( $75 \%$ ) felt that the Moto-Stand was better than a wheelchair, two $(10 \%)$ felt that the Moto-Stand was worse than a wheelchair, and three $(15 \%)$ felt that there was no difference between the two. The height accessibility (using the Moto-Stand), ranged between 60 to $270 \mathrm{cms}\left(2^{\prime}\right.$ to $\left.9^{\prime}\right)$ from the ground with a range of $62 \mathrm{cms} 210 \mathrm{cms}\left(2^{\prime}\right.$ to $\left.7^{\prime}\right)$.

When asked to comment on the overall function, 19 said the Moto-Stand was comfortable with one reporting it was uncomfortable. Seventeen subjects felt that it was safe, two felt that it was unsafe and the others had no comment.

\section{Discussion}

Paraplegics from $T_{4}$ to $L_{1}$ level were able to use the Moto-Stand without any assistance. It was quite obvious that the lower the level of the lesion, the better the ability of the subject to transfer to the Moto-Stand and back to the wheelchair. The subjects with high thoracic and cervical lesions felt nauseated initially due to postural hypotension, which cleared up after a short period. Moto-Stand could be used by three incomplete tetraplegics below $\mathrm{C}_{6}$ level but they needed minimum to moderate assistance. Those who were tetraplegic also needed to have reasonably good dexterity of their hands; without dexterity it would be impossible to use or manoeuvre the Moto-Stand, even if the subject could get on to the MotoStand with assistance. The number of years of disability did not appear to have any bearing on the ability to use the Moto-Stand. The older age group, however, was not as enthusiastic as the younger group and preferred the wheelchair for mobility. The subjects with moderate to severe spasticity appeared to perform worse on the Moto-Stand but flexion deformities of $20^{\circ}$ or less of hip and/or knee joints did not affect performance on Moto-Stand. Subjects who had the ability to do pushups in the wheelchair were consistently able to get on and off the Moto-Stand with ease. The Moto-Stand appeared to be superior in kitchen activities, especially when handling hot objects and the reaching for objects at different heights. This also holds good for activities to be done in limited spaces, such as a workshop. The space taken by the Moto-Stand to turn around was no greater than that of a wheelchair. The majority $(80 \%)$ of the subjects felt that the Moto-Stand is comfortable, safe, and could be used at work, if employment was considered. Those people who were walking with two crutches (or with braces and crutches), felt that the Moto-Stand would leave their hands free to pursue other activities.

\section{Conclusions}

The Moto-Stand can be used by most paraplegics between $\mathrm{T}_{4}$ and $\mathrm{L}_{1}$ levels without assistance. Incomplete tetraplegics up to $\mathrm{C}_{6}$ level may be able to use (but need moderate assistance), to get on to a Moto-Stand. They also need reasonable hand function to manipulate the controls. Although the number of years of disability has no bearing on the usefulness of this vehicle moderate to severe spasticity can definitely interfere with the use of a Moto-Stand. MotoStand is superior in the kitchen to a wheelchair, especially when handling hot objects and reaching for objects at different levels. Moto-Stand has superior manoeuverability and is safe on ramps. No tipping was seen when used on a 
$10^{\circ}$ gradient surface. The majority of the subjects tested felt that it is comfortable and safe.

\section{Résumé}

Couramment, tous les efforts à aider le déplacement des paraplégiques ont concentré à améliorer l'aspect, la durabilité, le poid et la vélocité du fauteuil roulant. Récemment, un véhicule électrique a été introduit pour servir à transporter les malades paraplégiques debouts. Le Moto-Stand donne aux personnes handicappées une grande capabilité à travailler et beaucoup plus de mobilité que le fauteuil roulant. Vingt malades portant des blessures à la moelle épinière de $\mathrm{C}_{6}$ à $\mathrm{L}_{1}$ ont utilisé le Moto-Stand pour l'évaluer. Trois malades avec des blessures cervicales avaient une tétraplégie qui n'était pas complète. Dix sept malades avaient des blessures entre $\mathrm{T}_{4}$ et $\mathrm{L}_{1}$. Tous ont été invalides pour deux à vingt deux années. On a trouvé que le malade peut utiliser le Moto-Stand mieux quand sa blessure est basse. On a conclus que les paraplégiques peuvent utiliser le Moto-Stand sans aide, mais les tétraplégiques doivent être aidés à s'élever. Le Moto-Stand est meilleur pour le travail dans la cuisine, surtout pour utiliser les objets chauds et pour atteindre les differants niveaux. Le Moto-Stand tourne en place et permet une meilleure maneuvrabilité dans une cuisine, dans la place d'émploi ou même dans une maison roulante (Trailer). À l'exception de deux, tous les malades l'ont trouvé confortable et facile a utiliser avec sécurité. Le Moto-Stand permet les malades d'arriver, avec les deux mains, à un niveau par-dessus la tête. Aussi, ils peuvent ramasser des objets de parterre parceque le Moto-Stand peut s'abasser avec un "power forward" spécial. Les malades avec spasticité sévère ou modérée ont plus de difficulté avec le Moto-Stand. La sécurité, le maintien et la durabilité du Moto-Stand étaient satisfaisants.

\section{Zusammenfassung}

Heutzutage werden alle Bemeuhungen der Fortbewegung der Paraplegischen zu helfen auf die Verbesserung des Baues, Staerke, Gewicht, u. Geschwindigkeit der Fahrstuele gerichtet. Unlaengst wurde ein Drinnenfahrzeug zur Fortbewegung der Paraplegishen vorgefuert. Der Moto-Stand gibt den Behinderten eine Reihe von Arbeitsmoeglichkeiten und erweitert die Grenzen der Fortbewegung weit ueher die der Fahrstuele. Zwanzig Erwachsene, spinal Verletzte mit C-6 und L-1 Verletzungen wurden fuer den Benutz des Moto-Stand bewaertet. 3 Patienten mit cerviculen verletzungen hatten unvollendete Quadruperese und die anderen 17 hatten Verletzungen zwischen T-4 und L-1. Das Alter dieser Gruppe war 2 bis 24 Jahre. Wir fanden das je niedrieger die Verletzung, desto besser der Nutz des Moto-Stand. Dieses Fahrzeug Kaunn von allen Paraplegieschen ohne Hilfe benutzt werden. Die Qudriplegishen brauchen Hilfe beim Aufstehen. Der Moto-Stand dreht auf eigener Achse und ist deshalb mehr nuetzlich fuer beschraenkte Raume wie z.B. die Kueche. Der patient hat die Haende frei und Kann nach Sachen ueber dem Kopf reichen oder aber auch Sachen vom Fusboden mit Hilfe eines spezialen "Staerke Vozwaerz" Biegung, aufheben. Patienten mit mittel, oder schwerer Verkrampfung haben mehr Schwierigkeiten mit dem Moto-Stand. Die Sieherheit, Pflege und Stabilitaetstests waren alle sehr bef riedigend.

\section{Acknowledgements}

We thank the staff and management of Veterans Administration Medical Center, Kansas City, MO, where the study was conducted. We also thank the Advanced Technology Corporation of Kansas City, MO 64141, for providing the equipment for the study.

\section{References}

Peizer E (1975) Wheelchairs: Atlas of Orthotics: Edited by American Academy of Orthopaedic

Surgeons. CV Mosby, St Louis, MO, p 431-453.

REDFORD JB 1980 Orthotics Etcetra. Williams and Wilkins, Baltimore, MD, p 480-493. 